\title{
Da cidade escravista à cidade moderna. Os limites de um projeto de integração conservadora no Rio de Janeiro entre 1903 e 1906
}

\section{From Slave town to modern city: the limits of a conservative integration project in Rio de Janeiro from 1903 to 1906}

\author{
André Nunes Azevedo*
}

\begin{abstract}
Resumo
Com a vinda da Corte portuguesa em 1808 o Rio de Janeiro passa a crescer em alta progressão. Esse crescimento lançou desafios à cidade, que deveria responder a uma nova ordem de demanda por serviços de infraestrutura urbana. A resposta do poder público a esse desafio foi através do braço escravo, que aumentou sobremaneira o vulto de sua presença nas ruas da urbe. Esse fenômeno colaborou para a formação de uma cultura de distensão na ocupação do espaço urbano. Essa cultura se configurou em um problema às elites gestoras do Brasil no contexto do fim da escravidão, início de um novo regime, crescimento exponencial da cidade e crescimento da economia capitalista, próprios do fim do século. O enfrentamento desse problema esbarrou nas contradições da solução da reforma urbana do prefeito Pereira Passos e sua ideia de civilização.
\end{abstract}

Palavras-Chaves: escravidão; cidade; Rio de Janeiro; civilização; reforma urbana.

\begin{abstract}
With the arrival of the Portuguese Court in 1808, Rio de Janeiro began to grow in high progression. This growth posed challenges to the city, which should respond to a new order of demand for urban infrastructure services. The government's response to this challenge was through slave labor, which greatly increased its presence in the large city streets. This phenomenon has contributed to the formation of a relaxed culture in the occupation of urban space. This culture has set up a problem to management elites of Brazil in the context of the end of slavery, the beginning of a new regime, exponential growth of the city and growth of the capitalist economy, particular the end of
\end{abstract}

\footnotetext{
* Doutor em História Social da Cultura pela PUC-Rio. Professor do PPGH em História Política da UERJ. E-mail: azevedoemigrante@gmail.com
} 
the $19^{\text {th }}$ century. Facing this problem has come up against the contradictions of the solution of urban reform of Mayor Pereira Passos and his idea of civilization.

Keywords: Slavery; city; Rio de Janeiro; civilization; urban reform.

\section{A cidade escravista no século XIX}

A tradição de utilização do espaço público do Rio de Janeiro remonta à experiência da escravidão na cidade. Ao longo do Século XIX a urbe carioca cresceu em acelerada progressão na esteira da vinda da corte portuguesa ao Brasil em 1808, e sua afirmação pouco depois, como capital de um novo país emergente em 1822. De uma população de 43.376 habitantes em 1799, o Rio de Janeiro passou a 112.695 moradores em 1821 e mais que dobrou esse contingente em 1849, onde registrou 268.386 pessoas. Avançou pouco deste último período até 1872, onde contou 274.972 residentes. Entre esse ano e 1890, mais um grande salto, que elevou a população da cidade aos 522.651 cidadãos. Em 1906, a beira da Grande Reforma Urbana do Rio de Janeiro, registrou-se a maior diferença populacional absoluta em um período de 10 anos. Nesse período os residentes da urbe carioca dispararam em aproximadamente 300.000 moradores, chegando a impressionante marca de 811.443 residentes. ${ }^{1} \mathrm{O}$ crescimento da cidade foi vertiginoso desde a chegada da Corte portuguesa. Ao longo do período de vigência da escravidão no Século XIX, a população da urbe aumentou incrivelmente, multiplicando em cerca de doze vezes o seu tamanho. Do início desse século até o seguinte, o aumento foi ainda maior, cerca de dezoito vezes o seu tamanho original de 1800 a 1906. Essa verdadeira explosão demográfica foi acompanhada de um aumento correspondente por serviços básicos, como dotação de água, iluminação pública, esgotamento sanitário, transportes, entre outros. A solução oferecida pelas autoridades públicas a esse desafio foi o braço escravo. ${ }^{2} \mathrm{O}$ aumento do número de cativos progrediu de acordo com o crescimento da população geral da urbe até

\footnotetext{
${ }^{1}$ Os dados fornecidos entre 1799 e 1849 foram extraídos de FLORENTINO, Manolo. Alforrias e etnicidade no Rio de Janeiro oitocentista: notas de pesquisa. Rio de Janeiro: Revista Topoi n.5, jul-dez de 2002. p. 10-11. Os dados relativos aos períodos apresentados entre 1872 e 1906 foram extraídos da tabela da população das cidades segundo os sensos demográficos, apresentada pelo IBGE. Ver: http://www.censo2010.ibge. gov.br/sinopse/index.php?dados $=6 \& u f=00$

${ }^{2}$ Cf. ALGRANTI, Leila M. O feitor ausente. Estudos sobre a escravidão urbana no Rio de Janeiro - 1808-1822. Petrópolis: Vozes, 1988. p. 73.
} 
meados do Oitocentos. Serviços como calçamento público, iluminação pública, transporte de cargas, suprimentos e pessoas pela cidade eram realizados pelo escravizado, muitas vezes pelos escravos prisioneiros do Calabouço. ${ }^{3} \mathrm{Em} 1799$ a população de cativos do Rio de Janeiro registrava 14.986 indivíduos, quase quadruplicando em um curto período de duas décadas, para 55.090 desafortunados em 1821, e dobrando esse contingente em 1849, onde se verificou o número de 110.622 escravos. ${ }^{4} \mathrm{Na}$ segunda metade do Século XIX o número de cativos foi caindo gradativamente por força da lei Eusébio de Queiroz, de 1850, que proibiu o tráfico negreiro no Brasil.

Acrescente-se aos prestadores de serviços básicos de infraestrutura a figura do negro de ganho. ${ }^{5}$ A escravidão de ganho foi um fenômeno social que deixou grande marca na tradição de usanças do espaço público do Rio de Janeiro. Juntamente com os escravos prestadores de serviço, a escravidão de ganho tornou o espaço urbano da cidade apinhado de cativos em labuta pela féria diária. ${ }^{6}$ Em adição à grande presença de cativos no Rio de Janeiro oitocentista, estava a massa de homens livres pobres que circulava pela urbe. Cabe marcar aqui que entre as principais ocupações da população ativa da cidade em 1870 estavam os "sem profissão conhecida", respondendo esse grupo a cerca de $35 \%$ do contingente de homens livres da cidade. ${ }^{7}$ Com efeito, as opções assumidas pela elite portuguesa e brasileira para responder ao rápido crescimento da cidade e sustentar as demandas do "mundo da ordem", ${ }^{8}$ resul-

$\overline{{ }^{3} \text { Cf. ALGRANTI, op. cit. p. }}$ 79-80.

${ }^{4}$ Cf. FLORENTINO, op. cit. p. 10-11.

${ }^{5}$ Os trabalhos que tomamos como referenciais para nossas considerações sobre a presença do escravo nas ruas do Rio de Janeiro são: SILVA, Marilene Rosa N. da. Negro na rua. A nova face da escravidão. São Paulo: Hucitec, 1988. SOARES, Luiz Carlos. O povo de Cam na capital do Brasil: a escravidão urbana no Rio de Janeiro do século XIX. Rio de Janeiro: Faperj - 7 Letras, 2007. KARASCH, Mary. A Vida dos Escravos no Rio de Janeiro 1808-1850. São Paulo: Cia das Letras, 2000. CHALHOUB, Sidney. Cidade febril. Cortiços e epidemias na Corte Imperial. São Paulo: Cia. das Letras, 1996. ALGRANTI, Op. cit e SOARES, Carlos Eugênio L., GOMES, Flávio S. e FARIAS, Juliana B.. No labirinto das nações. Africanos e identidades no Rio de Janeiro, século XIX. Rio de Janeiro: Arquivo Nacional, 2005.

${ }^{6} \mathrm{O}$ escravo de ganho foi cada vez mais presente nas ruas da cidade ao longo da primeira metade do Século XIX, e também fortemente presente na segunda metade desse século, até 1888. Consistia naquele cativo que era mandado sair às ruas a fim de conseguir uma certa quantia diária, estipulada pelo seu senhor, para entregar ao mesmo no fim do dia. 0 excedente dessa quantia poderia ficar com o escravo. Se não trouxesse o valor diário estabelecido seria castigado. Ver: SILVA, op. cit.

${ }^{7}$ Mensuração feita por mim com base nos dados do recenseamento de 1870 apresentados por Eulália Lobo. Ver: LOBO, Eulália L. História do Rio de Janeiro. Do capital comercial ao capital industrial e financeiro. Rio de Janeiro: IBMEC, 1978. v.1. p. 229.

${ }^{8}$ Me valho aqui da metáfora "mundo da ordem", para designar a elite branca, proprietária do Rio de Janeiro, que atuava tanto como homens públicos, ou altos funcionários públicos, vinculados ao Estado, como ao conjunto de proprietários das camadas médias e altas não vinculados ao Estado, que eram, via de regra, detentores de escravos. 
taram em um processo de imbricação histórica entre este mundo e o mundo das ruas do Rio de Janeiro, ou seja, o mundo dos escravos e dos homens livres pobres sem ocupação definida, que constituíam parte significativa da cidade.

A elite urbana do Rio de Janeiro foi usuária constante dos serviços prestados pelos negros de ganho. Consumia constantemente nas ruas da cidade os seus serviços de aguadeiro, sapateiro, funileiro, transportador, vendedor de alimentos, entre outros. Assim, dois universos sociais distintos, se entrelaçavam e desenvolviam uma relação de dependência mútua. Os mundos da "ordem" e o da "des-ordem" ${ }^{9}$ se alimentavam e se sustentavam mutuamente no Rio de Janeiro. A cultura urbana da cidade não pode ser compreendida sem uma remissão a essa imbricação entre segmentos tão distintos, porém integrados na dinâmica sociocultural do Rio de Janeiro.

A dicotomia entre esses segmentos produziu significativo efeito histórico na formação da cultura urbana do Rio de Janeiro. A imbricação e interdependência entre esses dois mundos impôs uma dinâmica de ocupação desregulamentada do espaço urbano da cidade, o que propiciou uma tradição daquilo que classifico como uma "ocupação distendida do espaço urbano" do Rio de Janeiro. Distensão aqui tem a conotação de algo relaxado, desprovido de rigidez que, portanto, não pauta a sua dinâmica de ocupação espacial pelo conjunto de leis, normas e posturas estabelecidas formalmente pelo poder público. A formação de uma cultura de distensão na forma de ocupação do espaço urbano da cidade supõe a sedimentação histórica de ações individuais orientadas pelos interesses privados, que expandem a sua individualidade ao espaço público da urbe em detrimento de uma ética coletiva que garanta que este mesmo espaço possa servir ao bem estar de toda a comunidade de seus usuários. Essa sedimentação histórica derivou da tolerância com a ocupação

\footnotetext{
${ }^{9}$ As metáforas "mundo da ordem" e mundo da "des-ordem", da qual nos utilizamos aqui, foram inspiradas no trabalho do Professor Ilmar de Mattos em seu já clássico livro O Tempo Saquarema. A formação do Estado Imperial. MATTOS, op. cit., 1986. p. 109-129. No entanto, faço aqui a observação de que não reproduzo exatamente o sentido de suas metáforas. Mattos entende o mundo da ordem como algo que engloba o mundo do trabalho escravo, controlado pela dominação dos seus senhores, e das elites proprietárias do Império. De forma distinta, utilizo essa metáfora para designar a elite branca, proprietária do Rio de Janeiro, que atuava tanto como homens públicos, ou altos funcionários públicos, vinculados ao Estado, como ao conjunto de proprietários das camadas médias e altas, não vinculados ao Estado, que eram, via de regra, detentores de escravos. No que diz respeito ao mundo da des-ordem, que propositalmente assinalo com um hífen, com o fito de representar a sua condição de par oposto ao mundo da ordem, entendo como as camadas despossuídas do Rio de Janeiro do século XIX, sobretudo escravos e libertos, mas também europeus meridionais pobres que perambulavam pelas ruas da cidade em busca da sua sobrevivência diária. Esclareço que o Professor Ilmar de Mattos usa essa metáfora para indicar apenas os homens livres pobres, que eram vistos como não tendo lugar nem ocupação na ordem legada pela colônia. Mattos faz essa utilização por abordar o influxo da tradição que vem da colônia ao Império. A minha designação dessa mesma terminologia é distinta, justamente por abordar o influxo da tradição que vai do Império à Primeira República.
} 
não regulamentada desse espaço por parte do poder público, que conferiu um alto grau de liberdade aos agentes privados quanto a sua ocupação, as suas formas de uso do espaço da cidade. Esse poder eletivo dos atores privados conta não só com a omissão do poder público no seu direito e dever de regulamentar essa ocupação, mas também com a anuência da sociedade, que extrai benefício desse aspecto da cultura urbana, a relação da sociedade carioca com o espaço da cidade.

O cotidiano da vida urbana do Rio de Janeiro oitocentista foi marcado por escravos, imigrantes ibéricos, alforriados e um grande contingente de homens livres pobres que andavam pela cidade a berrar, vendendo as suas mercadorias e serviços. Muito comuns foram as práticas da tavolagem, ${ }^{10}$ que se estabeleceram sem critério no espaço do centro da urbe. Figuras comuns no Rio de Janeiro do Século XIX eram os vendedores de perus lusitanos, que transitavam pelo Centro da cidade com os seus animais, bradando o anúncio de suas mercadorias; o vendedor de leite de vaca, que conduzia o animal de porta em porta; os carroceiros e transportadores de carga, ${ }^{11}$ escravos ou livres, muitas vezes ibéricos, que competiam por clientes com os cativos, e que deitavam mercadorias e quinquilharias em praticamente qualquer sítio do centro urbano, realizando um trânsito desregulamentado. ${ }^{12}$

Esse conjunto de trabalhadores braçais, sejam eles escravos ou livres, europeus ou brasileiros, ocuparam o espaço urbano do Rio de Janeiro todos os dias em busca de sua feria diária, que jogava um papel fundamental na sua sobrevivência e bem-estar. Para os homens livres pobres os ganhos diários representavam a manutenção biológica de si e, muitas vezes, da sua família. Para os escravos de ganho, a féria diária evitava a tortura que recairia sobre o seu corpo, e mesmo a possibilidade de executar o sonho da alforria, do qual dependia o seu desempenho a cada dia. Essa realidade de instabilidade e imprevisibilidade econômica, reveladora de uma situação de alta vulnerabilidade material, e forte dependência do desempenho diário do sucesso do seu trabalho, gerou o que denomino "economia da salvação diária", um fenômeno que deu a tônica da vida cotidiana nas ruas da urbe carioca. Essa economia da salvação diária, derivada da necessidade, insegurança e precariedade material do trabalhador desafortunado do Rio de Janeiro - que constituía a maioria

\footnotetext{
${ }^{10}$ Era como se designava na virada do século XIX ao XX a prática de pôr uma mesa à rua para vender as suas mercadorias em um comércio informal.

${ }^{11}$ EDMUNDO, Luis. O Rio de Janeiro do meu tempo. Distrito Federal: Senado Federal, 2003. p. 27-35.

${ }^{12}$ São várias as descrições da polifonia e confusão urbana do Rio de Janeiro oitocentista. Mas recomendamos em particular: EDMUNDO, op. cit., p. 25-37.
} 
dos habitantes da cidade - e a dependência do "mundo da ordem" para com essa massa de trabalhadores, foram os elementos que geraram a cultura de ocupação distendida do espaço urbano do Rio de Janeiro. Cabe lembrar que durante o século XIX foi a grande massa de trabalhadores que jogavam cotidianamente a incerteza de sua precária sustentação material nas ruas da cidade - escravos, ex escravos, biscateiros e homens livres que viviam da prática da viração -, que tocaram a maior parte dos trabalhos da vida cotidiana e mesmo da infraestrutura da urbe carioca.

Se tomarmos como base o quadro urbano que é desenhado pelos historiadores estudiosos da escravidão de ganho no Rio de Janeiro oitocentista, fica clara a ocupação maciça das ruas da cidade por esses cativos. ${ }^{13}$ Luiz Carlos Soares afirma que o povo de Cam eram os donos das ruas do Rio de Janeiro, e fundamenta essa afirmação citando três viajantes estrangeiros que emitiram relatos sobre a presença de negros de ganho nas ruas do Centro. Relembra o inglês Luccock, na década de 1810, quando relatava que antes das dez horas da manhã a presença de homens brancos era rara pelas ruas da cidade. Traz também a descrição do francês Edouard Manet, em 1849, quando esse europeu, confirmando as impressões de Luccock, reportou que apenas os negros e as negras podiam ser encontrados nas ruas da cidade durante o dia. Já quando Soares recorda a mirada do também francês Charles Expilly, em relato de 1862, traz a percepção desse estrangeiro de que, durante as horas mais quentes do dia, apenas escravos e cachorros podiam ser encontrados nas ruas. ${ }^{14}$

A presença massiva dos ganhadores cativos nas vias do Centro recebia também o contributo da indiferença de grande parte dos senhores desse tipo de escravo, que atiravam aos mesmos a responsabilidade pela sua alimentação, muito comumente feita na própria rua, na maioria das vezes através das barracas de angu, alimento barato, vendido por outros ganhadores urbanos. Ademais, era comum que não lhes designassem espaço em casa para o seu sono, tendo, boa parte deles, que dormir ao relento, nos logradouros públicos da cidade. ${ }^{15}$ A rigor, eram os próprios cativos ganhadores que organizavam o seu trabalho, decidiam o que fariam e como iriam executar a sua labuta, não raro o fazendo em grupos. ${ }^{16}$

\footnotetext{
${ }^{13}$ SOARES, Carlos Eugênio L., GOMES, Flávio S. e FARIAS, Juliana B.. No labirinto das nações. Africanos e identidades no Rio de Janeiro, século XIX. Rio de Janeiro: Arquivo Nacional, 2005. p.113

${ }^{14}$ SOARES, Luiz Carlos. O povo de Cam na capital do Brasil: a escravidão urbana no Rio de Janeiro do século XIX. Rio de Janeiro: Faperj - 7 Letras, 2007. p.86

${ }^{15}$ Ibidem. p. 97.

${ }^{16}$ SOARES, GOMES, e FARIAS, op. cit., p.113-114.
} 
Vale lembrar que embora a escravidão de ganho tenha diminuído de forma considerável no Rio de Janeiro após o fim do tráfico de africanos em 1850, ela ainda continuou vultuosa em sua presença na urbe carioca da segunda metade do século XIX. Mesmo até a beira da Lei Áurea, em 1888, quando a escravidão era diminuta na Corte, viam-se carregadores cativos, no ganho, circulando pelas ruas da cidade. ${ }^{17}$ Devemos marcar também que a ocupação do espaço urbano por gente empregue na atividade de ganho, através da prestação de serviços no Centro do Rio de Janeiro, não se restringiu somente aos escravos ganhadores. A urbe carioca apresentou um grande fluxo imigratório português na segunda metade do século XIX, boa parte dos quais se lançou à área central da cidade em atividades de ganho com serviços urbanos. Fizeram parte da paisagem urbana do Rio de Janeiro de então, muito comumente perambulando pelas ruas estreitas da urbe imperial. Não raro se apresentavam gritando a anunciar as suas mercadorias e serviços, descalços e sem camisa, muitas vezes em flagrante concorrência com os serviços prestados pelos negros de ganho. O censo de 1872 apresentou o impressionante número de 55.938 lusitanos, 20,3\% da população total da cidade registrado naquele ano, que contava 274.972 residentes. ${ }^{18} \mathrm{Em}$ acréscimo à presença portuguesa e escrava na ocupação das ruas do Centro da cidade, merece especial destaque também a enorme presença de libertos no Rio de Janeiro, grande parte dos quais retirando o seu sustento das atividades de ganho nos logradouros da região central. ${ }^{19}$ Segundo cálculos de Soares (2007) sobre números do censo de 1872, a urbe carioca registrou 53.509 pessoas libertas ou descendentes de libertos nesse ano, ${ }^{20}$ cerca de $20 \%$ da população da Corte. Esse mesmo censo registrou $15,2 \%$ de escravos para o total da população residente na urbe carioca. ${ }^{21}$

Em acréscimo aos prestadores de serviço e adeptos da prática da viração, devemos acrescentar os capoeiras, elementos indissociáveis da paisagem urbana do Rio de Janeiro do século XIX. Andando em maltas, verdadeiros bandos, muitas vezes rivais, esses habitantes da urbe carioca desfilavam pelas ruas do Centro com sua vestimenta típica: calças largas de bocas estreitas, lenço ao pescoço, sapatos de salto "carrapeta", chapéu branco com fita amarela e/ou vermelha, além do porte da navalha, sempre inseparável. ${ }^{22}$ Eram

\footnotetext{
${ }^{17}$ SOARES, op. cit., p.124.

${ }^{18}$ Ver: IBGE, op. cit.

${ }^{19}$ SOARES, GOMES, e FARIAS, op. cit., 113.

${ }^{20}$ SOARES, op. cit., p. 301.

${ }^{21}$ SOARES, GOMES, FARIAS, op. cit., 113.

${ }^{22}$ CRULS, Gastão. A aparência do Rio de Janeiro. Rio de Janeiro: José Olympio, 1965. p.407.
} 
lutadores exímios na arte de origem africana. Circulavam pelas ruas da cidade promovendo brigas entre si e com a polícia, em grande frequência, além de atuarem como guarda-costas de políticos, justiceiros contratados, além de agirem em motins nas ruas da cidade, conforme nos indica Carlos Eugênio Líbano Soares. ${ }^{23}$

Não obstante os imigrantes portugueses, negros libertos ou capoeiras colaborarem decisivamente para a cultura de ocupação distendida do espaço urbano do Rio de Janeiro, não resta dúvida de que a opção da elite lusitana pela mão de obra escrava, com o fito de resolver a demanda por serviços urbanos, foi o elemento central que promoveu esse traço da cultura carioca. A chegada da Corte do Príncipe Regente D. João gerou um repentino aumento de demanda por serviços urbanos, que constituiu um desafio a ser rapidamente resolvido pelas autoridades públicas portuguesas, responsáveis pela gestão de uma cidade em rápido crescimento. Após a emancipação política, pós 1822, as elites brasileiras optaram por manter a solução portuguesa que, por seu turno, marcava, de maneira ampliada, a continuidade da solução colonial para a prestação de serviços urbanos.

Cabe notar que no Rio de Janeiro do século XIX os escravos eram proibidos de andarem calçados pela cidade, e que, diversas regulamentações emanadas pelas posturas do poder público eram patentemente relaxadas pelas autoridades, pois feririam a dinâmica econômica da urbe, da qual a mesma dependia para o seu funcionamento, pois a escravidão urbana impunha uma realidade sistêmica, ligada à subsistência de todas as camadas sociais da cidade..$^{24}$ Cabe marcar também que o poder público não foi capaz de fiscalizar as regulamentações que instituía quanto à ocupação do espaço urbano da cidade, considerando-se a densidade urbana dessa região da corte, denominada por Chalhoub como "cidade esconderijo" 25 e o vulto da presença de escravos circulando pela zona urbana do Rio de Janeiro, que fazia com que tais regulamentações de posturas e regras urbanas se verificassem apenas no papel. ${ }^{26}$

Além da prestação de serviços urbanos essenciais, como a iluminação pública, dotação de água, esgotamento sanitário, transporte de cargas e pessoas, a escravidão de ganho dava sustento a um expressivo número de famílias

\footnotetext{
${ }^{23}$ Soares, Carlos Eugênio L. A capoeira escrava e outras tradições rebeldes no Rio de Janeiro (1808-1850). Campinas: Ed. da Unicamp, 2001. p. 323-413.

${ }^{24}$ SOARES, Luiz Carlos. O povo de Cam na capital do Brasil: a escravidão urbana no Rio de Janeiro do século XIX. Rio de Janeiro: Faperj - 7 Letras, 2007. p. 129.

${ }^{25} \mathrm{Cf}$. CHALHOUB, op. cit.

${ }^{26}$ SOARES, GOMES e FARIAS, op. cit., 115.
} 
de homens livres, bem como alimentava boa parte da população, consertava, construía e mantinha muito do que existia no Rio de Janeiro.

A implicação da massificação da escravidão urbana na cidade como forma de atender às demandas em uma metrópole em rápido crescimento pela sua mudança de status foi a criação de uma cultura de ocupação distendida do espaço urbano carioca. A historiografia sobre a escravidão no Rio de Janeiro, fundada, em muito, no relato de estrangeiros, foi vasta na ilustração das situações que davam nota do processo de constituição dessa maneira espontânea de ocupar o espaço da urbe. Mary Karasch chama a atenção para a presença massiva de escravos de ganho nas ruas da cidade, vendendo de porta em porta, perambulando pela cidade e sobrepondo seus berros a anunciar seus produtos e serviços nas vias públicas do Centro carioca, ou a estender panos ao chão, no qual exibiam as suas mercadorias, ou barracas precárias em praças públicas, ruas, largos, praias e beiras de igrejas. ${ }^{27} \mathrm{O}$ assédio dos ganhadores nas ruas do Rio de Janeiro era constante, invasivo e, de tal ordem desagradável, que os estrangeiros constantemente queixavam-se dos vendedores de rua que os cercavam, ávidos pela conquista de sua féria diária, pois nela se jogava cotidianamente a economia da (sua) salvação diária, uma vez que dela dependiam não só para o excedente que lhes validaria o sonho da tão desejada alforria, como, sobretudo, o fariam escapar dos espancamentos de seus senhores diante do não cumprimento de sua cota pré-estabelecida. ${ }^{28} \mathrm{~A}$ economia da salvação diária e suas formas arrojadas de abordagem e ocupação do espaço público da cidade guardavam íntima relação com o drama cotidiano vivido pelos escravos ganhadores, com medo permanente dos espancamentos e castigos que, sabiam, seriam infligidos em seus corpos pelos seus amos, ansiosos pela féria diária, muitos dos quais também jogavam aí a economia da (sua) salvação diária. Some-se a isso a ambição de vários senhores, que obrigavam os seus escravos às práticas mais heterodoxas para obterem o seu lucro diário. Eles tornaram comuns nas ruas cariocas atividades de ganho como a prostituição e a mendicância. Até mesmo escravos cegos, doentes e incapacitados eram obrigados por seus amos a se estabelecerem nas ruas da urbe, a fim de mendigar dinheiro, que iria diretamente aos bolsos de seus proprietários, ${ }^{29}$ fato que ajudou a apinhar de mendigos e pedintes as ruas do Centro da cidade.

\footnotetext{
${ }^{27}$ Cf. KARASCH, Mary. A Vida dos Escravos no Rio de Janeiro 1808-1850. São Paulo: Cia das Letras, 2000. ${ }^{28}$ Ibidem. p. 284.

${ }^{29}$ Ibidem. p. 285.
} 
Nas ruas da cidade também foram muito comuns as procissões constantes de carregadores, com volumes à cabeça, levando carnes, peixes, animais vivos, mobiliários, bagagens, água, madeiras, entre diversas outras coisas. Segundo Luiz Carlos Soares, os viajantes nacionais ou estrangeiros, quando desembarcavam na cidade pelo Cais Pharoux, eram prontamente acossados pelos ganhadores que se ofereciam para transportar as suas malas à cabeça. Soares rememora os relatos dos irmãos Louis e Georges Verbrugghe, que desembarcaram na urbe carioca na década de 1870 . Os europeus teriam descido ao cais com mais nove viajantes, e se viram na contingência de fazer uso do serviço de 11 escravos de ganho, acompanhando-os em uma longa procissão de onze cativos, atravessando as ruas mais abarrotadas da cidade, sempre estreitas, até chegarem ao seu hotel de destino. ${ }^{30}$

As escravas ganhadoras também tomavam o espaço urbano carioca a sua maneira. Segundo Karasch, as roupas eram lavadas em pelos menos três diferentes áreas: nas Laranjeiras, na fonte mais central do Rio de Janeiro, no Largo da Carioca e na fonte do Campo de Santana, principal local de lavagem de roupas da cidade. Nessa última, segundo a historiadora norte americana, em média, duzentas pessoas esfregavam roupas. No Largo da Carioca os escravos batiam as roupas nos muros próximos e estendiam-nas no chão para as secar. ${ }^{31}$ No local eram também comuns rusgas e brigas pela disputa da água para as mais diversas finalidades.

O espaço urbano do Rio de Janeiro imperial também foi marcado pela presença dos "tigres", escravos que carregavam tonéis repletos de excrementos das casas da Corte. Fétidos, não raro marcados pelos vazamentos do conteúdo nauseante que carregavam à cabeça, esses cativos eram figuras comuns a circular pelo espaço urbano carioca em um deplorável cortejo pelas ruas estreitas da cidade, se misturando às caravanas de negros carregadores de malas a cabeça, aos carroceiros, aos escravos com as suas bancas de mercadorias, gente montada a cavalo, e aos gritos dos ganhadores ambulantes, sejam eles escravos, libertos ou imigrantes portugueses; estes últimos a andar com as suas vacas leiteiras ou seu bando de perus a vender pelos logradouros e vias da urbe.

o Campo de Santana servia como principal destino dos despejos clandestinos feitos pelos tigres. Nesse mesmo lugar - que na década de 1870 se tornaria um belo e bucólico bois urbaine, construído por Auguste Glaziou,

\footnotetext{
${ }^{30}$ SOARES, op.cit., p. 129-130.

${ }^{31} \mathrm{KARASCH}$, op. cit., p. 288.
} 
no melhor estilo parisiense Haussmanianno - os senhores mandavam os seus escravos lançarem toda sorte de lixo que se poderia imaginar. Segundo Frédéric Mauro, lá eram lançados cadáveres de cães, de burros, de gatos, louça quebrada, chapéus e vestimentas sem uso, além dos já mencionados excrementos domésticos. ${ }^{32}$ Todo esse material em decomposição oferecia um odor nauseabundo que avançava em vários metros de distância deste que fora o maior depósito de lixo a céu aberto do Rio de Janeiro. Mas esses rejeitos não se acumulavam somente nesse ponto da cidade. Vários eram os lugares do centro da Corte onde montes de lixo se empilhavam. Um dos mais centrais e conhecidos da cidade era o Largo do Paço, onde se localizava um dos palácios imperiais. Mauro, recobrando as narrativas do francês Expilly, chama atenção para o desmazelo do governo e da sociedade carioca para com os seus logradouros públicos. Estarrecido, e sem pudores em esconder o seu desprezo de europeu oitocentista por esses desafortunados, assim era descrito o Largo do Paço pelo gaulês: "Por trás de um pedaço de muro que foi deixado em pé, não consigo advinhar por que se amontoam negros maltrapilhos e cobertos de bichos. Sem respeito pelos demais e por si mesmos, eles fazem ali as suas necessidades, à maneira de macacos mal-educados". ${ }^{33} \mathrm{O}$ mesmo observador do Velho Continente afirmou que os habitantes franceses do Rio de Janeiro apelidaram essa praça como Largo aux chamber-pots, ou seja: "Largo dos penicos!". ${ }^{44}$

Toda a história de ocupação distendida do espaço urbano daquela que na segunda metade do Oitocentos ficou conhecida como "cidade pestilenta" só foi possível, como já frisamos, pela simbiose entre os mundos da "ordem" e da "des-ordem" no Rio de Janeiro. Para além de todo sistema de interdependências que foi jogado no século XIX escravista entre as camadas baixas, médias e altas da sociedade carioca, essa imbricação era, ela mesma, promovida de forma institucional pelo poder público imperial. Para termos a dimensão exata disso, basta demarcarmos aqui que os escravos de ganho só podiam circular nas ruas de maneira legal, com a autorização expressa e licença da Câmara Municipal. Era terminantemente proibido que os cativos perambulassem em atividade de ganho sem a chancela do poder público..$^{35}$ Segundo Soares, os senhores deveriam remeter um pedido à Câmara Municipal, e realizar o

\footnotetext{
${ }^{32}$ MAURO, Frédéric. O Brasil no tempo de D. Pedro II.: 1831-1889. São Paulo: Cia. das Letras, 1991. p. 21

${ }^{33}$ MAURO, op. cit., p. 20

${ }^{34}$ Ibidem.

${ }^{35}$ SOARES, op. cit., p. 125.
} 
pagamento de $1 \$ 000$ relativos a cada escravo que designassem para o ganho nas ruas da cidade. Quando de posse da autorização, os proprietários desses cativos recebiam do poder público municipal chapas numeradas com as datas de sua emissão, as quais os escravos ganhadores deveriam portar. A sua validade era de um ano, e findo esse período, os senhores deveriam repetir o procedimento, a fim de que o "mundo da ordem" conferisse legitimidade de atuação ao mundo da "des-ordem". Se o cativo de ganho fosse flagrado sem a sua chapa municipal, o procedimento era o da recolha do mesmo ao Depósito público e a aplicação de uma multa ao seu proprietário, condição para a sua liberação. ${ }^{36}$ Para termos uma ideia de como o fenômeno da escravidão de ganho foi vultuoso na urbe carioca imperial, vale dizer que, em dado momento, imigrantes espanhóis e italianos solicitaram ao poder público municipal licenças de "negro de ganho"!. ${ }^{37}$

Assim, a tradição de ocupação distendida do espaço do Rio de Janeiro que se constituiu com a massificação do trabalho escravo urbano, desde a vinda da Corte portuguesa à cidade em 1808, até o final da escravidão, em 1888, foi um produto da simbiose entre os "mundos da ordem" e o da "des-ordem", constituída pela opção das elites portuguesa e brasileira em fundear toda a infraestrutura e economia da cidade na mão de obra cativa. O fizeram a fim de atender às demandas de uma urbe em acelerado crescimento. Com efeito, essa tradição foi constituída por um lento processo de maturação através da experiência histórica de vivências naquela que foi a maior cidade escravista do Ocidente durante a quase totalidade do século XIX. Não só os proprietários de cativos dependiam dos rendimentos auferidos pelos seus escravos de ganho. Toda a sociedade carioca funcionou estribada no labor escravo, o que implica entendermos que toda a infraestrutura da cidade - água, esgotamento sanitário, transporte, entre outras, foi realizada por essa mão de obra. Mas não só isso, pois a maior parte dos homens livres da urbe carioca compravam mercadorias e serviços os mais diversos, cotidianamente, nas mãos desses escravos que, por seu turno, deles também dependiam para manterem a sua integridade física, reprodução biológica, mínimo de sanidade - ainda que muito precária - e, o que lhes tinha grande peso, o sonho da tão desejada alforria que, bem sabiam, na maioria das vezes só poderia lhes assistir na interação com a massa de homens livres que também circulavam pelas ruas da cidade. Foi essa dinâmica sócio-econômica que fez com que o Rio de Janeiro tornasse

\footnotetext{
${ }^{36}$ Ibidem.

${ }^{37} \mathrm{KARASCH}$, op. cit., p. 284.
} 
socialmente imbricados os "mundos da ordem" e o da "des-ordem", pois se, por um lado, esses dois mundos eram tão estanques, por outro, guardam grande interdependência, sendo a constituição de um incompreensível sem a dinâmica da relação estabelecida com o outro.

Não se poderia cobrar a observância por parte dos escravos das detalhadas posturas urbanas da cidade, pois a cada dia que ocupavam o espaço urbano do Rio de Janeiro, jogavam o drama da "economia da salvação diária". Sua alimentação, sanidade mínima, integridade física e psicológica e mesmo a expectativa de sua liberdade, eram jogadas cotidianamente nas ruas, praças, largos e demais logradouros da corte.

Em acréscimo às práticas dos escravos, não podemos deixar de frisar a luta pela sobrevivência cotidiana de todos os homens livres pobres da cidade. Nela, como já frisamos anteriormente, cerca de $35 \%$ de todos eles se situavam na categoria "sem ocupação definida", o que indica que a maior parte desse contingente vivia de eventuais biscates, e da prática da viração, tão comum na luta pela manutenção da vida no Rio de Janeiro do século XIX. Muitos desses brancos e libertos despossuídos concorriam com os escravos na disputa pela faina de cada dia, no dia-a-dia da cidade, atuando a despeito de qualquer código de posturas, do qual muito provavelmente, a maioria sequer teria ouvido falar. Dentro desse verdadeiro "exército de despossuídos" não escravizados também se encontravam os imigrantes portugueses que, como já assinalamos, chegaram a cerca de $20 \%$ dos habitantes da urbe em 1872, mais ou menos o mesmo número dos libertos e seus descendentes que viviam então na Corte. A maioria dos lusitanos que cá estavam nessa altura eram gente de poucas posses, baixa renda, parco nível de instrução e que também atuava de forma dramática no cenário urbano carioca na busca de seu sustento diário. Descalços e sem camisa, como os escravos, competiam também com esses na gritaria do comércio ambulante e na condição de transportadores pelas ruas estreitas do Rio de Janeiro. Toda essa massa de gente despossuída: escravos, libertos e portugueses, foram elementos decisivos na construção de uma cultura distendida de ocupação do espaço urbano da maior cidade imperial. Ainda mais decisivos que esses foram os gestores públicos, portugueses e brasileiros, que fizeram a opção por fazer a cidade funcionar movida, sobretudo, pela mão de obra escrava e suas formas mais dramáticas de atuação urbana, como na economia da salvação diária gerada pela escravidão de ganho, que criou uma sistemática de funcionamento da vida econômica da urbe que tornou pouco viável a fiscalização e o cumprimento das posturas urbanas designadas pelas leis e normas vigentes na Corte. 


\section{A cidade e suas transformações em fins do século XIX}

Com base no que expusemos até aqui, cabe notar que o século XIX sedimenta uma tradição de uso distendido do espaço urbano do Rio de Janeiro, uma forma de uso que respondia às demandas de uma metrópole em rápido crescimento através da escravidão urbana tal como foi articulada na cidade, bem como as dimensões que a mesma apresentava, ainda registrando uma população inferior aos 300 mil habitantes em 1872, na última década e meia de seu período escravista. Não obstante, o final da década de 1880 e o início do decênio seguinte imporiam transformações que impactariam significativamente na, então, maior cidade brasileira. A primeira delas é a abolição da escravidão, que subtrairia grande contingente de mão de obra do campo com a desmobilização da força de trabalho atuante nas fazendas do interior de diversas regiões do Sudeste, remetendo um contingente populacional expressivo para o Rio de Janeiro, principal centro econômico do país e, portanto, propiciador de maiores oportunidades para o desafio da garantia da sobrevivência dessa mão de obra. ${ }^{38}$ Muitos dos escravos que antes atuavam nas casas ou chácaras dos seus senhores passaram também agora a acorrer às regiões mais próximas ao Centro, lugar de maior concentração de oportunidades de ganhos materiais, mesmo que através de trabalhos eventuais e incertos, como era comum empregar-se boa parte da mão de obra do Rio de Janeiro. Assim, um grande contingente de ex escravos e homens livres pobres evadidos das antigas unidades agrícolas de produção escravista, castigadas por severa crise, passam a circular pelas ruas da cidade a busca de sua economia da salvação diária. No entanto, o fariam agora sem o instrumento tradicional de controle social que era a escravidão. A instauração de um novo regime com o golpe republicano também encetaria transformações marcantes na urbe carioca. Uma das principais providências do Governo de Deodoro da Fonseca foi a facilitação da naturalização de portugueses em 1890, disposição legal que aumentou sobremodo a imigração de lusitanos para a Capital Federal. A expressiva crise econômica que atingiu Portugal no período entre 1888 e 1895 também incrementou a imigração portuguesa para a principal cidade brasileira, ${ }^{39}$ majorando o contingente de população em precária condição

\footnotetext{
${ }^{38} \mathrm{Cf}$. LOBO, Eulália. História do Rio de Janeiro. Do capital comercial ao capital industrial e financeiro. Rio de Janeiro: IBMEC, 1978. v.2. p. 469. A professora Eulália Lobo corrobora a posição defendida pelas pesquisas de Stein quanto ao vulto da evasão de mão de obra das fazendas de café do Ale do Paraíba Fluminense em direção ao Rio de Janeiro. Ver: STEIN, Stanley. Grandeza e decadência do café. São Paulo: Brasiliense, 1961. ${ }^{39} \mathrm{Cf}$. LOBO, Eulália. Imigração portuguesa no Brasil. São Paulo: Hucitec, 2001. p. 15-22.
} 
material, sobretudo habitacional, na cidade..$^{40}$ No mesmo início da década de 1890 o fenômeno econômico do Encilhamento, aprofundado na gestão ministerial de Rui Barbosa, criou uma série de oportunidades no início da última década do século XIX, bem como reforçou no imaginário nacional a ideia de que o Rio de Janeiro era um lugar de grandes oportunidades, no qual os indivíduos mais empreendedores quase fatalmente se sucederiam com grande prosperidade, fato que somou para atração de novos contingentes para a, então, principal cidade do Brasil. ${ }^{41}$

O Rio de Janeiro aumentou a sua população de maneira exponencial após esse conjunto de transformações. O fenômeno migratório e imigratório ambos impulsionados pelo fim da escravidão e as transformações executadas pelo novo regime político levaram o Rio de Janeiro a registrar no início do novo século um contingente expressivo de $55 \%$ de sua população com origem exógena à cidade..$^{42} \mathrm{Com}$ efeito, o fim da escravidão teve significativo impacto na constituição da do Rio de Janeiro como uma urbe que atraia grande diversidade pessoas. Toda essa massa de migrantes e imigrantes também colaborou sobremaneira para o aumento da população da cidade. De 522.651 habitantes em 1890, o Rio de Janeiro salta a 811.443 moradores em $1906 .{ }^{43}$ Esse crescimento populacional acelerado também impactou nas condições de alojamento na Capital Federal. Nela prevaleciam formas de habitação populares as mais insalubres, como os cortiços, as casas de cômodos e as hospedagens baratas, conhecidas como "zungas", todas apresentando as piores condições habitacionais.

A instauração do novo regime teve ainda outras consequências para a cidade. Enquanto capital da República, o Rio de Janeiro foi lugar de uma miríade de revoltas. A instabilidade originada do processo de construção de

\footnotetext{
${ }^{40} \mathrm{O}$ trabalho mais expressivo em dados sobre essa crise é o de: CARVALHO, Lia Aquino de. Habitações populares. Rio de Janeiro: Secretaria Municipal de Cultura, 1995. Ver sobretudo a seção descritiva sobre a situação da população precariamente alojada na cidade, entre as páginas 132-153.

${ }^{41} \mathrm{~A}$ imagem do Rio de Janeiro como lugar das grandes oportunidades como derivação do fenômeno do encilhamento pode ser observada no romance de Taunay, que escreve sobre o codinome Perdigão Malheiros. Ver: TAUNAY, Alfredo. O Encilhamento: Cenas contemporâneas na bolsa do Rio de Janeiro em 1890, 1891 e 1892. Rio de Janeiro: Melhoramentos, 1893.

${ }^{42}$ Assinalamos que José Murilo de Carvalho, oferecendo números do censo de 1890 , dá nota de $28,7 \%$ da população do Rio de Janeiro originária do exterior, e $26 \%$ provenientes de outras regiões do Brasil. Ver: CARVALHO J. M., Os bestializados. O Rio de Janeiro e a República que não foi. São Paulo: Cia. das Letras, 1987. p.17

${ }^{43}$ Os dados relativos aos períodos apresentados entre 1872 e 1900 foram extraídos da tabela da população das cidades segundo os sensos demográficos, apresentada pelo IBGE. Ver: http://www.censo2010.ibge. gov.br/sinopse/index.php?dados $=6 \& u f=00$
} 
uma nova ordem política impactou na vida urbana carioca. A metrópole, que já era percebida como um espaço confuso, comparada a uma cidade bazar oriental e, ainda, repleta de epidemias e endemias, passou a ser notada também como cidade rebelde. ${ }^{44}$ Foi lugar de grande número de revoltas, rebeliões e quarteladas, que se estenderam pelas duas décadas iniciais do novo regime. O Rio de Janeiro da virada do século foi, antes de mais nada, uma cidade conturbada politicamente, com formas espontâneas de ocupação do espaço urbano, originadas da experiência da cidade escravista, pestilências as mais diversas e, ainda, uma sucessão de rebeliões presentes nos primeiros quinze anos do novo regime. Não foi sem sentido que o historiador Nicolau Svcenko designou a cidade como "inferno social". ${ }^{45}$

Para além de todo o crescimento populacional apresentado, cabe ainda marcar a importância da desvinculação da economia brasileira da escravidão. A abolição do cativeiro legalizado impulsionou o desenvolvimento do capitalismo na urbe. Capitais antes mobilizados na produção escravista agora passam a ser investidos na Capital Federal, centro econômico do país. ${ }^{46}$ A fartura de mão de obra disponível e o rescaldo do encilhamento, que em meio a uma série de falências ainda registrou resultado final positivo no desenvolvimento de empresas privadas, também colaboraram para o desenvolvimento e expansão do capital na cidade. A nova relação com o mundo material ensejada com a experiência do encilhamento, valorizadora do consumo e da ostentação de bens importados como forma de legitimação social, também contribui para criar um empuxo de demanda por bens de consumo na maior cidade do país. $\mathrm{Na}$ Capital Federal, a elite brasileira sediada no Rio de Janeiro manifestava a sua parisina, a prática de cultuar os bens culturais e símbolos de consumo ligados à capital francesa. No dizer do estudioso norte-americano Jeffrey Needell, a elite da urbe carioca apresentava um fetichismo de consumo, repleta de

\footnotetext{
${ }^{44} \mathrm{O}$ trabalho de Santucci traz-nos um quadro dessas revoltas no início do século XX. Ver: SANTUCCI, Jane. Cidade rebelde. As revoltas populares no Rio de Janeiro do início do século XX. Rio de Janeiro: Casa da Palavra, 2008. No entanto, as revoltas da última década do século XIX foram mais avultadas em quantidade do que aquelas da urbe carioca do início do século XX, para não mencionarmos a sucessão de agitações operárias no período, que chegaram ao seu ponto culminante com a greve geral de 1903. Para além da Revolta da armada, e da tentativa de deposição de Prudente de Moraes por um golpe de Estado, as revoltas mais célebres no período, também acometeram a cidade diversas revoltas militares, principiadas, sobretudo, na Urca e na Vila Militar. Para se ter um panorama desse conjunto de revoltas, ver: CARVALHO, José Murilo de. Forças armadas na Primeira República: o poder desestabilizador. In: FAUSTO, Boris (org.). O Brasil republicano. N. 9. Tomo III. $2^{\circ}$ vol. Sociedade e Instituições (1889-1930). Rio de Janeiro: Bertrand Brasil, 1990.

${ }^{45} \mathrm{Cf}$. SVCENKO, Nicolau. A literatura como missão. Tensões sociais e criação cultural na Primeira República. São Paulo: Cia das Letras, 2003, p. 72-94.
}

${ }^{46}$ STEIN, Stanley. Origens e evolução da indústria têxtil no Brasil. 1850-1950. Rio de Janeiro: Campus, 1979. 
salões literários, confeitarias e lojas de mercadorias francesas chiques ${ }^{47}$ Para Edmilson Rodrigues, o Rio de Janeiro vivenciava o sonho de uma sociedade de consumo de massa sem o ser. ${ }^{48}$ Esse conjunto de fatores convergiram não só para uma significativa expansão da economia capitalista na cidade, como também a tornaram o principal centro de consumo e circulação de mercadorias importadas do país.

Em suma, no alvorecer do século XX tínhamos uma metrópole em exponencial crescimento, com aumento progressivo de circulação de pessoas, transportes e mercadorias pelas ruas do Centro, região de alta concentração da atividade econômica da urbe; o aprofundamento das pestilências e epidemias que avançavam havia cerca de cinquenta anos na cidade e, o que nos interessa em especial, a necessidade que as elites da Capital Federal tinham - na ausência do instrumento de controle tradicional da escravidão - de articular um novo instrumento de controle social da massa de desvalidos da cidade politicamente mais convulsionada do país, e na qual tudo o que ocorria ganhava uma repercussão e proporção tamanhas em âmbito nacional, por força da capitalidade que portava. ${ }^{49}$

A solução encontrada pelas elites presentes na capital brasileira para resolver esses problemas da metrópole em veloz transformação foi a execução de uma Grande Reforma Urbana no Rio de Janeiro, a maior da história da cidade. Um empréstimo vultuoso foi contratado pelo Governo de Rodrigues Alves junto à banca dos Rotschilds em Londres, em valores inéditos na história econômica do Brasil. ${ }^{50}$

O Governo Federal ficou com atribuições muito específicas no interior dessa Grande Reforma, a ele caberia o que tomava como a sua principal obra: o porto. Em função da reformulação portuária, o Governo de Rodrigues Alves assumiria também obras que concebia como correlatas à intervenção do porto, a saber, a Avenida do Cais, que o margeava - atual Avenida Rodrigues Alves, a Avenida do Canal do Mangue - atual Francisco Bicalho, que tinha a função de escoar as mercadorias aportadas na urbe para a região da atual Zona Norte do Rio de Janeiro, e a Avenida Central, que cumpria o intuito de distribuir

\footnotetext{
${ }^{47}$ Cf. NEEEDELL, Jeffrey. Belle Époque tropical. São Paulo: Cia. das Letras, 1993.

${ }^{48}$ RODRIGUES, Antônio Edmilson. A modernidade carioca: o Rio de Janeiro do início do século XX. Mentalidade e vida literária. Rio de Janeiro: Tese de Livre Docência apresentada à UERJ, 1987 (mimeo.).

${ }^{49} \mathrm{O}$ conceito de capitalidade com o qual lidamos aqui é o apresentado por Azevedo. Ver: AZEVEDO, André N. A capitalidade do Rio de Janeiro: um exercício de reflexão histórica. IN: AZEVEDO, André N. (org.). Rio de Janeiro: Capital e capitalidade. Rio de Janeiro: Depext/UERJ, 2002.

${ }^{50}$ Cf. BENCHIMOL, Jaime. Pereira Passos: um Haussmann tropical. Rio de Janeiro: Secretaria Municipal de Cultura, 1992. p. 251-255.
} 
pelo centro urbano, principal área econômica da cidade, essas mercadorias que chegavam por via marítima.

A competência do Governo Municipal na Grande Reforma Urbana de 1903-1906 abarcaria as incumbências restantes àquelas sob a responsabilidade do Governo Federal. À municipalidade caberia a reformulação da estrutura viária da cidade, operando o alargamento de ruas, abertura de avenidas, estabelecimento de articulações viárias, drenagens dos rios, secamento do solo, e controle das posturas municipais e regulamentação das formas de uso do espaço urbano..$^{51}$

É essa parte da Grande Reforma Urbana, a cargo do Município, que nos interessa particularmente. O projeto de reformulação urbana desenvolvido por Pereira Passos tinha como valor maior a orientar a sua intervenção urbanística a ideia de civilização ${ }^{52}$ uma ideia de matriz europeia, própria das sociedades urbanas do Velho Continente dos anos 1800. O sentido de civilização que advinha dessas sociedades, e que Pereira Passos tencionava fazer valer no Rio de Janeiro da primeira década do século XX, dava nota de uma civilidade urbana, advinda da disciplina na ocupação desse espaço por regras, e pela ideia de auto-controle do indivíduo, que conteria a expansão de sua individualidade, a partir das balizas das leis, em nome do bem-estar de sua comunidade..$^{53}$ Supunha também princípios como polidez, desenvolvimento do gosto estético, progresso científico e material e uma ordem política estável. ${ }^{54}$

Foi tomando por base os pressupostos da noção europeia de civilização contemporânea que o Prefeito do Rio de Janeiro buscou estabelecer controle sobre a nova massa de trabalhadores urbanos que se avultavam cada vez mais na cidade. Para isso, delineou duas estratégias como fundamentais: primeiro, o amplo uso de proibições urbanas, decretadas já nos seus primeiros dias de administração, e diante de um Conselho Municipal fechado durante os seis primeiros meses de seu mandato. Proibiu cuspir na rua, escarrar nos bondes, andar descalço na urbe, fazer fogueiras, a venda de leite com vaca de porta em porta, a venda de carnes e vísceras em bancas pelas ruas, sem a devida

\footnotetext{
${ }^{51}$ Essa divisão de atribuições é acusada pelos trabalhos de BENCHIMOL. Op. Cit. e de ROCHA, Oswaldo P. A era das demolições. Rio de Janeiro: Secretaria Municipal de Cultura, 1995.

${ }^{52}$ Essa ideia está presente na tese de doutoramento de Azevedo. Ver: AZEVEDO, André N. Da Monarquia à República: um estudo dos conceitos de civilização e progresso na cidade do Rio de Janeiro entre 1868 e 1906. Rio de Janeiro: Tese de doutoramento apresentada à PUC-Rio, 2003 (mimeo.).

${ }^{53}$ Ver: BENVENISTE, Émile. Civilización. Contribuición a la historia de la palabra. IN: Problemas de linguística general. México Districto Federal. Siglo Veintiuno, 1994. p. 212.

${ }^{54} \mathrm{Cf}$. NICÉFORO, Alfredo. Les índices numériques de la civilization et Du progrès. Paris: Flammarion, 1921. p. 114 .
} 
fiscalização municipal, a proibição da circulação de cães vadios, da venda de loterias, e do que chamava prática da tavolagem, que consistia no comércio paralelo de rua, não oficializado pelo poder público..$^{55}$ Segundo, apostou no fomento ao gosto estético através de uma reformulação arquitetônica da cidade, e mesmo de sua estrutura urbanística. Em sua cadastral, plano orientador de seu projeto de reformulação urbana do Rio de Janeiro, afirma que o saneamento da Capital Federal passa pela sua reformulação estética. ${ }^{56}$ Participa como o principal membro da Comissão julgadora do Concurso de Fachadas da Avenida Central, a qual não aceitava prédios menores do que três pavimentos - de três a cinco andares -, e que toma por base nos seus juízos o que entendiam como a beleza das fachadas, via de regra, frontispícios de inspiração europeia ou de civilizações orientais, como a mourisca ou persa ${ }^{57}$ Pensa a presença do transeunte na cidade a partir de uma nova escala, diminuindo-o ante a grandeza da civilização através do artifício da articulação de prédios altos com avenidas e ruas alargadas, com novas praças amplas, arborizadas e urbanizadas, que aumentam a escala urbana, e com a presença de instituições de cultura traduzidas em uma arquitetura grandiloquente, tais como o Teatro Municipal, que constrói propositalmente em região programada para receber o novo e imponente prédio da Escola Nacional de Belas Artes, e o edifício da Biblioteca Nacional.

No seu projeto havia uma intencionalidade de sedução estética pela estrutura urbanística e arquitetura propostas. A ideia do Prefeito era a de atrair a população da cidade ao seu Centro reformado, que buscou constituir como lugar pedagógico da civilização, de uma nova civilidade na metrópole. Para isso criou três ligações viárias do centro com os subúrbios, além de deixar prontos os estudos e levantamentos topográficos para a construção de uma quarta ligação Centro-subúrbio através de uma avenida sinuosa de 33 metros, que ligaria a área reformada da cidade com a atual região da Tijuca, em um traço próximo ao estabelecido posteriormente pela Avenida Radial Oeste da Cidade. Com o mesmo intuito construiu uma vila operária na área central do Rio de Janeiro, na Avenida Frei Caneca, deixou mais duas em construção, no entorno do Centro, na Glória, no antigo Beco do Rio, que margeava a atual Rua

\footnotetext{
${ }^{55}$ Ver: Mensagem do Prefeito do Distrito Federal Lida na Sessão do Conselho Municipal de 3 de abril de 1903. Rio de Janeiro: Typographia da Gazeta de Notícias, 1906. p. 25.

${ }^{56}$ Prefeitura do Distrito Federal. Melhoramentos da cidade projetados pelo Prefeito do Distrito Federal Dr. Francisco Pereira Passos. Rio de Janeiro: Typographia da Gazeta de Notícias, 1903. p. 4.

${ }^{57}$ Sobre os critérios da Comissão avaliadora do Concurso de Fachadas, ver: FERREZ, Marc. O Álbum da Avenida Central. Rio de Janeiro: João Fortes Engenharia/Ex Libris, 1983.
} 
Antônio Mendes Campos, e na área central, na Rua São Leopoldo..$^{58}$ Além disso, reforma sete praças na área central da urbe, e constrói coretos de música em várias delas, com o fim de que bandas de música tocassem nesses logradouros nos domingos, a fim de oferecer diversão à população que intentava atrair ao Centro nos finais de semana. Com esse fim, reurbaniza também o Passeio Público, e nele constrói um aquário de água salgada, o maior da América do Sul, a fim de que se tornasse uma atração para a população carioca. De fato, o novo aquário do Passeio registra alto afluxo de pessoas em seu primeiro ano de funcionamento.

O prefeito, seja nos seus discursos, nos seus projetos urbanísticos e arquitetônicos ou nas suas ações de intervenção urbana, demonstrou interesse em trazer a população da cidade ao Centro, uma vez que o entendia como lugar modelar da civilização, meio de controle de uma massa popular urbana que crescia em alta progressão. Tinha um projeto de integração conservadora, ${ }^{59}$ que buscava ordenar a população da cidade de forma hierarquizada, considerando que elevaria culturalmente esses segmentos sociais, que tratava como "obreiros da civilização", ${ }^{60}$ ou seja, como atores menores do que entendia como sendo um processo civilizador, mas também compreendidos nele, de forma hierarquizada, tal como alunos incipientes sobre os valores que, reputava como sendo dignos de serem cultuados por um "povo civilizado". E aí reside a nossa questão. A noção de civilização acalentada por Pereira Passos era exógena à cidade. Clara e flagrantemente de matriz europeia. $O$ prefeito visa substituir o entrudo pela batalha de flores. Realiza a queima de fogos veneziana no Rio de Janeiro, traz à urbe carioca o teatro infantil Guignol, e mesmo o seu aquário de água salgada é inspirado em um congênere italiano, de Nápoles. Como pudemos observar na primeira parte desse texto, à qual agora retornamos, projetando o seu sentido em nossa argumentação, a historicidade do Rio de Janeiro foi profundamente vincada pela experiência da escravidão urbana. A sede da Corte foi nada menos do que a maior cidade escravista de todo o Ocidente no século XIX, e a última nesse âmbito a aboli-la. A maior parte da infraestrutura urbana da cidade fora operada pelo braço escravo, bem como boa parte de seu comércio e serviços. Outra parte

\footnotetext{
${ }^{58} \mathrm{Cf}$. Mensagem do Prefeito do Distrito Federal Lida na Sessão do Conselho Municipal de 5 de setembro de 1906. Rio de Janeiro: Typographia da Gazeta de Notícias, 1906. p. 14.

${ }^{59}$ Ver: BOBBIO, Norberto et al. Dicionário de política. Verbete conservadorismo. Brasília: Ed. UNB, 2010. 2v.

${ }^{60}$ A designação dos operários como "obreiros da civilização" é do próprio Passos, em discurso no Conselho Municipal. Ver: Mensagem do Prefeito do Distrito Federal Lida na Sessão do Conselho Municipal de 5 de setembro de 1906. Rio de Janeiro: Typographia da Gazeta de Notícias, 1906. p. 19.
} 
desses serviços urbanos foi prestada por libertos e por lusitanos, espanhóis e italianos aldeões, todos majoritariamente atuando sem segurança material, de acordo com os serviços que poderiam conseguir com o arrojo de sua atuação na cidade. Escravos, libertos e europeus meridionais jogavam, inclusive disputando entre si, a sua economia da salvação diária, responsável pela sua reprodução biológica, de suas famílias, e muitas vezes, no caso do escravo de ganho, de sua integridade física e de seu sonho de liberdade pela compra da sua alforria com o excedente de sua féria diária, devida ao seu senhor. Com um contingente de cerca de $35 \%$ da população da cidade sem ocupação definida, uma massa de escravizados e de pequenos empreendedores individuais a ocupar as ruas do Rio de Janeiro, sejam com os seus perus andar atrás de si para venda, seja com a vaca leiteira a correr de porta em porta para o comércio do leite, seja pela prestação de serviços de rua, como o transporte de mercadorias ou pessoas, ou a gritar como ambulantes a busca de vender os seus produtos, certo era que, com tal configuração sócio-econômica, uma tradição de ocupação distendida do espaço urbano da cidade se sedimentava em uma urbe com grande densidade urbana e populacional, como foi o Rio de Janeiro do século XIX. O poder público, incapaz de articular soluções alternativas a essas práticas junto à sociedade, mostrou-se complacente com a distensão na ocupação do espaço público da cidade. Talvez essa preocupação não lhe fosse tão premente, considerando-se as limitações que a escravidão oferecia ao desenvolvimento de uma economia capitalista, o que retardou o vulto da demanda por grande circulação de mercadorias pelas ruas da cidade, pela capacidade que esse arranjo sócio-econômico de oferta de serviços urbanos ainda apresentava, embora de maneira progressivamente precária, para dar soluções às demandas da urbe e, principalmente, pelo fato da vigência da escravidão apresentar-se ainda como uma forma de controle social, controle esse que a cidade não mais pode contar após a abolição da escravatura, em maio de 1888.

A reforma urbana de Pereira Passos, de maneira quixotesca, como dão nota a introdução da queima de fogos veneziana, da batalha das flores em substituição a festa popular do entrudo e outras iniciativas, procurou enfrentar a contrapelo a tradição da metrópole carioca. Buscou, na ausência da escravidão como forma de controle e coesão social, fazer valer uma ideia de civilização de matriz europeia, estranha aos hábitos e costumes há muito sedimentados na cidade. $\mathrm{O}$ fez entendendo civilização como palavra no singular, que não admitia variações, entendendo que se seria ou não civilizado. No conceito do Prefeito reformador, caso o cidadão não o fosse, deveria aprender 
a sê-lo, sobretudo através da coerção das proibições e da sedução por um novo enlevo estético e urbanístico de um Centro reformado. Não obstante, o caráter exógeno dessa civilização singular encontrou limites na historicidade do Rio de Janeiro, e na sua tradição de ocupação distendida do espaço urbano. A população da cidade, embora satisfeita alumbrada com a beleza do Centro reformado, continuou a urinar nos logradouros, dormir nas ruas, denunciando a crise de habitação na maior metrópole do Brasil, bem como a jogar lixo e escarrar no chão. A maior metáfora do malogro do projeto de integração conservadora do alcaide, de sua tentativa de disciplinamento da população carioca para uma civilidade burguesa europeia, foi o fato em torno da instauração de vários mictórios finamente adornados e com maçanetas de bronze que espalhou pelo Centro da urbe, com o fim de evitar o tradicional odor fétido de urina seca, característico do Centro do Rio de Janeiro. Na manhã seguinte a essas instalações sanitárias, todas as maçanetas haviam desaparecido. Tinham sido furtadas. Diante da proposta de sedução estética em favor dos padrões da civilização europeia, a economia da salvação diária continuou a prevalecer. A sedutora proposta do prefeito carioca encontrou os seus limites na historicidade da cidade.

Artigo recebido para publicação em 26/09/2016

Artigo aprovado para publicação em 03/11/2016 